\title{
SISTEM INFORMASI PEMBELIAN TIKET SPEED BOAT BERBASIS WEBSITE
}

\author{
${ }^{1}$ M. Afdal, ${ }^{2}$ Syahrul Hijaji \\ 1,2Program Studi Sistem Informasi, Fakultas Sains dan Teknologi, UIN SUSKA Riau, \\ Jl. HR Soebrantas, KM. 18.5, No. 155, Simpang Baru, Pekanbaru, Indonesia, 28293. \\ Email: ${ }^{1}$ m.afdal@uin-suska.ac.id, ${ }^{2}$ syahrulhijaji@gmail.com
}

\begin{abstract}
ABSTRAK
Speed boat merupakan salah satu transportasi laut yang banyak digunakan masyarakat untuk melakukan perjalanan antar pulau. PT. Sinar Romindo Indah merupakan perusahaan pelayaran rakyat yang berada di Tembilahan. Perusahaan ini memiliki tiga cabang agen resmi diantaranya Tembilahan, Guntung, dan Batam serta memiliki 9 armada speed boat, perusahaan ini beroperasi setiap hari dari pukul 08.00 WIB hingga pukul 16.00 WIB, setiap harinya perusahaan ini melakukan satu keberangkatan di masing-masing agen. Sulitnya bagi calon peumpang yang ingin mendapatkan tiket menjadi permasalahan pada perusahaan ini, dikarnakan calon penumpang harus selalu mengunjungi loket untuk membeli tiket dan jika terjadi lonjakan penumpang maka penumpang harus mengantri untuk mendapatkan tiket. Perusahaan juga harus mengeluarkan dana lebih untuk mencetak tiket di tempat lain dan tiket yang di gunakan berbentuk kertas sangat rawan rusak dan sobek sehingga sulit untuk di ketahui identitas penumpang tersebut. Adapun tujuan dari penelitian ini untuk membantu perusahaan dalam memperbaiki pelayanan pemesanan tiket secara online melalui website, hasil penelitian ini yaitu sistem informasi pemesanan tiket speed boat berbasis web pada PT. Pada pengujian blackbox, dapat diambil kesimpulan bahwa sistem informasi pemesanan tiket speed boat berbasis web dapat diterima dengan baik oleh user (pelanggan) maupun pihak perusahaan. Hasil pengujian user acceptance test menunjukan kinerja sistem $84 \%$, interface $89 \%$, kemudahan menggunakan sistem 88\%, Kelancaran sistem 81\%, ketepatan informasi $89 \%$, kelengkapan informasi $81 \%$, dan penilaian sistem secara keseluruhan $85 \%$.
\end{abstract}

Kata Kunci: pembeliaan, sistem informasi, speed boat, tiket

\section{A. PENDAHULUAN}

Jasa transportasi telah menjadi kebutuhan dasar masyarakat. Angkutan umum telah diklasifikasikan sebagai mode perjalanan yang penting [1]. Seperti halnya moda transportas air menjadi yang terpopuler di Tembilahan pada saat ini, dikarnakan Tembilahan memiliki jalur perairan yang sangat luas yaitu $7.207 \mathrm{Km}^{2}$ [2]. maka di butuhkan transportasi air yang dapat membawa penumpang dengan banyak dan cepat sehingga dapat membantu roda perekonomian dan bisnis. Seiring dengan berkembangnya ilmu pengetahuan dan teknologi, komputer sudah merupakan kebutuhan pokok bagi setiap instansi, perusahaan dan organisasi.

Pemanfaatan teknologi dalam perusahaan tidak hanya mendukung proses bisnisnya saja tetapi juga sangat berpengaruh terhadap keuntungan yang di peroleh perusahaan. Hal ini juga membuat para pemilik perusahaan terus mengembangkan inovasi yang dapat memberi kemudahan dan kenyamanan dengan menggunakan teknologi dalam bisnis mereka. PT. Sinar Romindo Indah merupakan salah satu perusahaan yang bergerak dibidang pelayaran angkutan speed boat, perusahaan ini berdiri pada 21 januari 1990 yang di pimpin oleh Saleh, perusahaan ini memiliki 3 agen resmi yaitu Tembilahan, Guntung, dan Batam. Saat ini proses bisnis yang sedang berjalan pada PT. Sinar Romindo Indah masih kurang efektif dikarenakan calon penumpang yang hendak berangkat harus mendatangi loket untuk memesan tiket, keterbatasan waktu dan biaya yang dimiliki calon penumpang menjadi kendala utama pada perusahaan ini, setelah calon penumpang berada diloket maka calon penumpang akan memesan tiket sesuai dengan rute yang diinginkan lalu membayar biaya tiket tersebut, selanjutnya calon penumpang menunggu keberangkatan sampai waktu keberangkatan tiba. Untuk menjaga stok ketersediaan tiket perusahaan harus mencetak tiket terlebih dahulu agar tiket bisa diberikan kepada calon penumpang, proses ini membutuhkan biaya yang besar yaitu Rp. 3000 untuk setiap tiketnya.

Perusahaan ini beroperasi setiap hari dari pukul 07:00 hingga 12:00 Wib. memiliki 9 unit speed boat yang beroperasi yaitu Tobindo Express, Rahmat Jaya 08, dan Rahmat Jaya 09, yang memiliki kapasitas angkut sebanyak 80, 112, hingga 130 penumpang dengan rute tujuan (Batam,Guntung,dan Tembilahan). Harga tiket sesuai dengan rute tujuan yang diinginkan mulai dari Rp.100.000 hingga Rp.500.000. dalam sehari perusahaan ini bisa melayani sebanyak 100 orang calon penumpang. Berdasarkan hasil wawancara yang dilakukan pada PT. Sinar Romindo Indah terdapat beberapa masalah yang terjadi dalam proses pemesanan tiket. Untuk mengetahui lebih jelas apa yang menjadi masalah dalam penelitian ini dilakukan wawancara dengan karyawan PT. Sinar Romindo Indah pada bagian 
loket pemesanan tiket. Permasalahan tersebut diantaranya sulitnya calon penumpang yang jauh dari loket untuk memesan tiket. Banyaknya dana yang di butuhkan perusahaan untuk mencetak tiket yaitu sebesar Rp.3000 setiap tiketnya. Pencatatan data penumpang yang masih kurang efektif. Kertas tiket mudah sobek rusak bahkan hilang. Sulitnya calon penumpang yang ingin mendapatkan informasi seperti harga, rute, dan jadwal keberangkatan.

Sistem informasi merupakan solusi untuk mengatsi masalah pada PT. Sinar Romindo Indah. Pemesanan tiket perjalanan secara online berbasis web bertujuan untuk memberikan alternatif kemudahan serta efisiensi waktu dalam pemesanan tiket dan informasi jadwal keberangkatan kota tujuan [3]. Aspek dari pemesanan tiket secara online ini merupakan salah satu bagian yang penting dari pemasaran. Apabila dapat meningkatkan penjualan dengan cara ini akan memberikan dampak positif bagi kemajuan usaha-usaha kecil di masa datang [4].

Diharapkan dengan adanya sistem informasi pemesanan tiket berbasis Web dapat memberi kemudahan serta kenyamanan bagi calon penumpang untuk memesan tiket dimanapun dan kapanpun selama 24 jam, menghemat biaya pencetakan tiket, mempermudah penyampaian informasi, serta keamanan tiket yang lebih baik. Sistm informasi pemesanan tiket berbasis web pada PT. Sinar Romindo Indah, dapat memberi kemudahan dan kenyamanan penggunanya dalam memesan tiket menggunakan perangkat dekstop yang dapat juga di operasikan pada perangkat mobile tanpa harus datang jauh ke loket, sehingga lebih efisien dan efektif. Keadaan ini mendorong suatu usaha untuk membangun suatu aplikasi pemesanan tiket berbasis web pada PT. Sinar Romindo Indah.

\section{B. METODOLOGI}

Penelitian ini terdiri dari empat tahap, yaitu: (1) tahap perencanaan; (2) tahap pengumpulan data; (3) tahap analisa dan perancangan; dan (4) tahap implementasi dan testing. Pada tahap perencanaan dilakukan kegiatan: (1) identifikasi masalah; (2) perumusan masalah; dan (3) penentuan batasan masalah. Pada tahap pengumpulan data, dilakukan studi literatur dan wawancara. Pada tahap analisa dan perancangan dilakukan Analisa dan perancangan untuk sistem usulan. Pada tahap implementasi dilakukan proses pengkodingan dan pengujian sistem menggunakan metode blackbox (interface dan form validation). Setelah sistem selesai dalam tahap coding dan testing, maka hal selanjutnya adalah mendapatkan feedback dari perusahaan atas sistem tersebut.

\section{HASIL DAN PEMBAHASAN}

\section{D.1. Analisa Sistem Sedang Berjalan}

Berikut ini adalah uraian secara umum sistem yang sedang berjalan pada proses pemesanan tiket speed boat PT. Sinar Romindo Indah:

(1) pelanggan yang ingin memesan tiket datang keloket;

(2) setelah pelanggan berada diloket pelanggan memesan tiket seperti memilih rute tujuan dan jadwal keberangkatan yang diinginkan;

(3) setelah pelanggan mendapatkan tiket pelanggan langsung membayar biaya tiket;

(4) setelah membayar tiket pelanggan sudah bisa mendapatkan tiket keberangkatan

Berikut merupakan gambar use case diagram sistem yang sedang berjalan saat ini pada PT. Sinar Romindo Indah dapat dilihat pada Gambar 1.

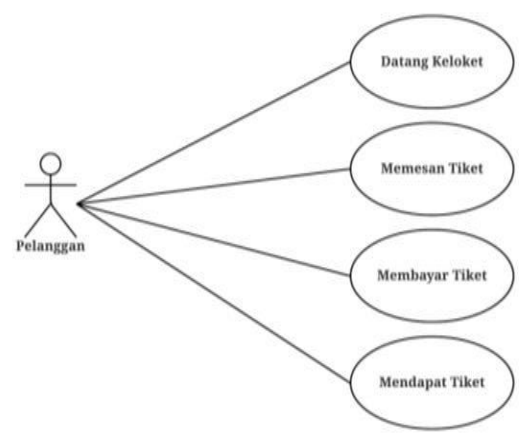

Gambar 1. Use case pelanggan sistem sedang berjalan

\section{D.2. Analisis Sistem Usulan}

\section{D.2.1. Use Case Diagram Admin}

Berikut use case diagram sistem usulan pelanggan pada sistem informasi pemesanan tiket speed boat dapat dilihat pada Gambar 2.

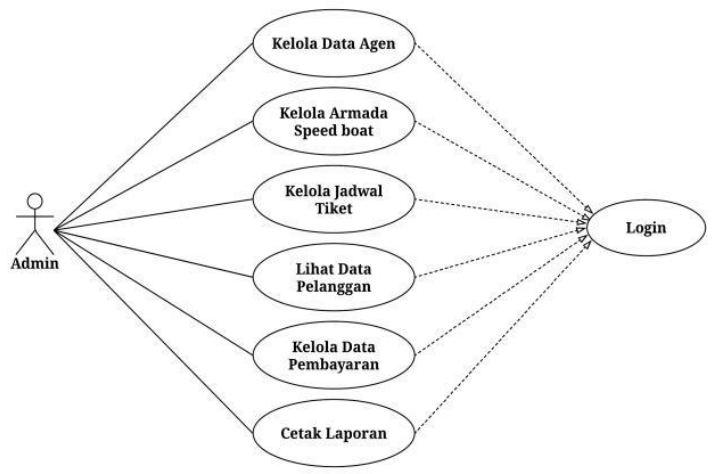

Gambar 2. Sistem usulan admin

\section{D.2.2. Use Case Diagram Agen}

Berikut use case diagram sistem usulan agen pada sistem informasi pemesana tiket speed boat dapat dilihat pada Gambar 3.

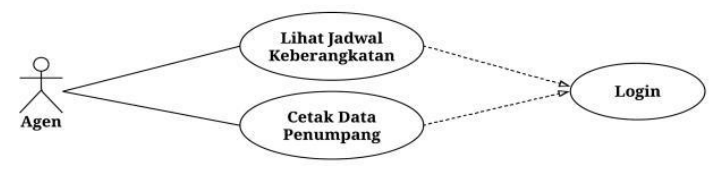

Gambar 3. Sistem usulan agen 


\section{D.2.3. Use Case Diagram Pelanggan}

Berikut use case diagram sistem usulan pelanggan pada sistem informasi pemesanan tiket speed boat dapat dilihat pada Gambar 4.

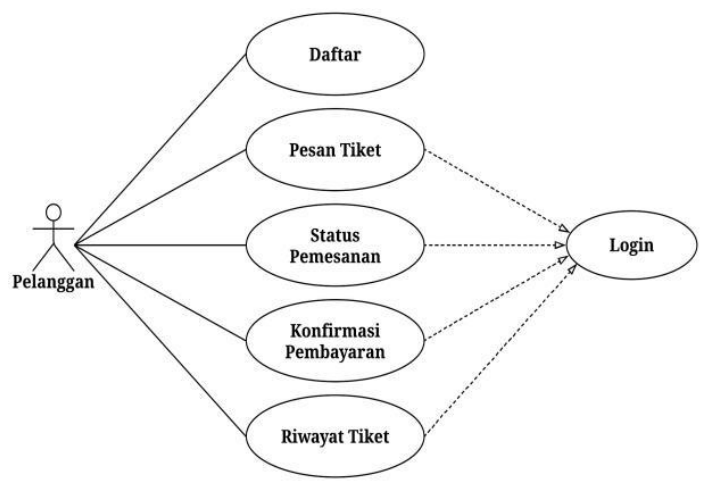

Gambar 4. Sistem usulan pelanggan

\section{D.3. Hasil Sistem}

\section{D.3.1. Halaman Awal Sistem}

Halaman ini merupakan tampilan awal sistem bagi pelanggan yang mengunjungi sistem informasi pemesanan tiket speed boat PT. Sinar Romindo Indah. Tampilan awal sistem dapat dilihat pada Gambar 5.

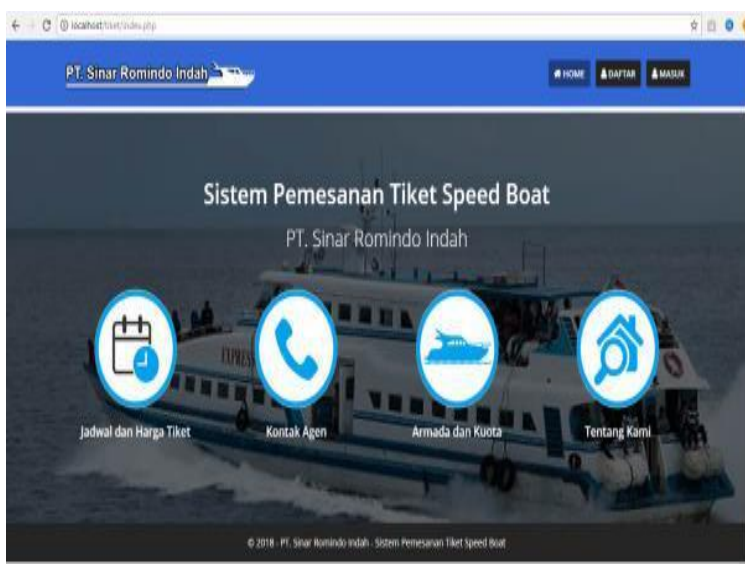

Gambar 5. Halaman awal sistem

\section{D.3.2. Halaman Login}

Halaman ini merupakan tampilan menu login yang difungsikan untuk user yang akan login kedalam sistem sperti admin, agen, dan pelanggan. Tampilan menu utama pelanggan dapat dilihat pada Gambar 6.

\section{D.3.3. Halaman Menu Utama Pelanggan}

Halaman ini merupakan tampilan menu utama pelanggan ketika ketika berhasil login kedalam sistem, tampilan ini memiliki fungsi yaitu pesan tiket, konfirmasi pembayaran, riwayat tiket, dan edit profil. Tampilan menu utama pelanggan dapat dilihat pada Gambar 7.

\section{D.3.4. Halaman Pesan Tiket}

Halaman ini merupakan tampilan bagi pelanggan yang ingin memesan tiket, di dalam tampilan ini terdapat pilihan untuk keberangkatan asal, tujuan, dan waktu keberangkatan. Tampilan halaman pesan tiket dapat dilihat pada Gambar 8 .

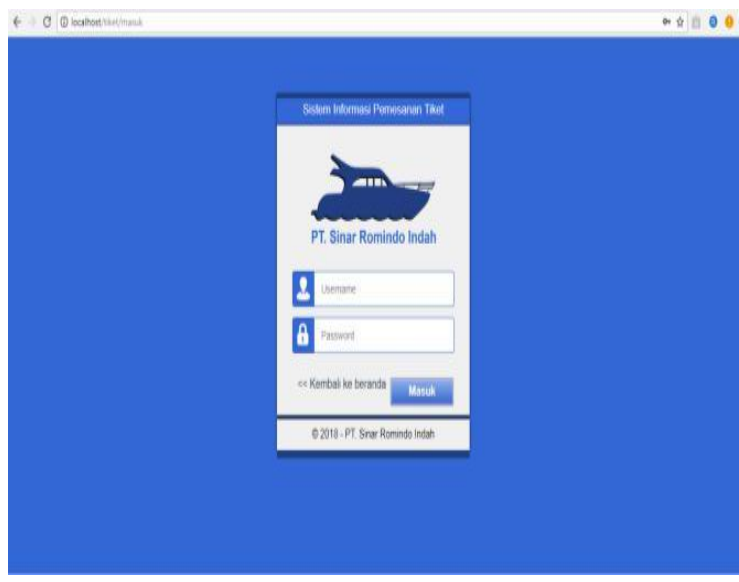

Gambar 6. Halaman login

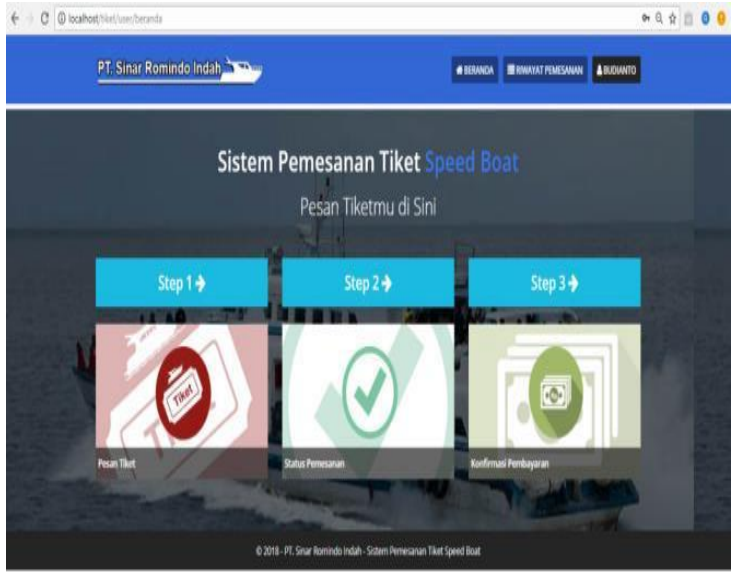

Gambar 7. Halaman menu utama pelanggan

\section{D.3.5. Halaman Menu Admin}

Tampilan ini merupakan halaman utama admin ketika admin masuk kedalam sistem, tampilan ini berisi menu gerafik informasi jumlah penumpang, dan menu navigasi sistem. Tampilan halaman laporan keberangkatan dapat dilihat pada Gambar 9.

\section{D.4. Pengujian Sistem \\ D.4.1. Pengujian Metode Blackbox}

Pengujian ini dilakukan dengan penemuan kesalahan yang diakibatkan dari interaksi yang tidak diharapkan pada setiap subsistem dengan hasil yang diharapkan. Seperti proses pemasukan perubahan, serta penghapusan data dengan memasukan sampel data yang didapatkan dari PT. Sinar Romindo Indah dan pengujian dilakukan menggunakan blackbox testing. Proses uji pada blackbox testing ditampilkan dalam bentuk tabel yang didalamnya menjelaskan tentang deskripsi pengujian, prosedur pengujian, hasil yang diharapkan, dan kriteria evaluasi hasil seperti berhasil atau tidaknya pengujian. Pengujian blackbox testing pada interface dan form validation, adalah semua tombol $100 \%$ berjalan dengan berasil. 
Jurnal Ilmiah Rekayasa dan Manajemen Sistem Informasi, Vol. 4, No. 2, Agustus 2018, Hal. 138-141 e-ISSN 2502-8995, p-ISSN 2460-8181

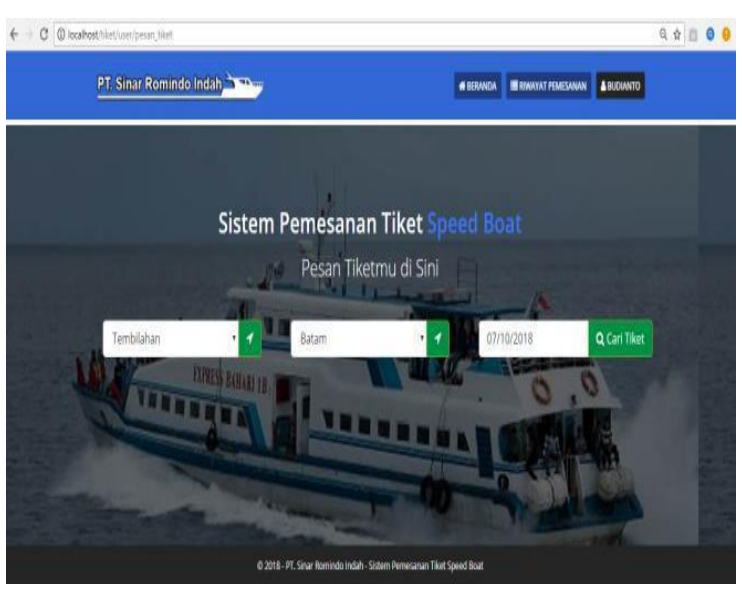

Gambar 8. Halaman pesan tiket

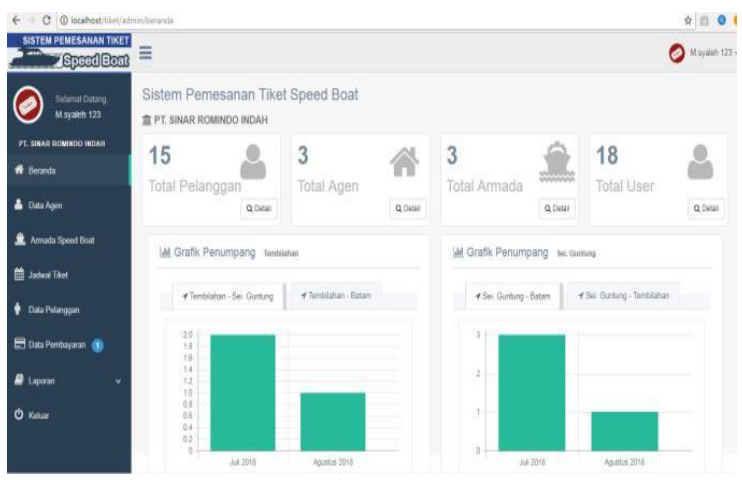

Gambar 9. Halaman menu admin

\section{D.4.2. Pengujian User Acceptance Test (UAT)}

Pengujian user acceptencetest merupakan pengujian yang dilakukan berdasarkan hasil kuesioner yang sebelumnya telah dibagikan kepada user sebanyak 15 orang responden, dalam hal ini terdiri dari satu admin, tiga agen, dan sebelas pelanggan tiket speed boat.

Pengujian dilakukan dengan cara user menggunakan sistem dan kemudian user mengisi form pengujian user acceptance test yang berisi peniliaan dan saran. Berdasarkan hasil kuesioner yang telah dibagikan kepada user, dapat dihiyung skor setiap aspek penilaian dengan indikator yang digunakan ini adalah: (1) kinerja system; (2) interface (tampilan antar muka dari sistem); (3) kemudahan menggunakan system; (4) kelancaran system; (5) ketepatan informasi; (6) kelengkapan informasi; (7) penilaian sistem secara keseluruhan.

Hasil perhitungan menggunakan user acceptance test yaitu seperti Tabel 1 .

Tabel 1. Hasil Pengujian Sistem

\begin{tabular}{llllllll}
\hline \multirow{2}{*}{$\begin{array}{l}\text { Respon } \\
\text { den }\end{array}$} & \multicolumn{7}{l}{ Nilai Dari Indikator } \\
\cline { 2 - 7 } & $\mathbf{1}$ & $\mathbf{2}$ & $\mathbf{3}$ & $\mathbf{4}$ & $\mathbf{5}$ & $\mathbf{6}$ & $\mathbf{7}$ \\
\hline A & 5 & 4 & 4 & 3 & 5 & 4 & 5 \\
B & 5 & 5 & 4 & 4 & 4 & 4 & 5 \\
C & 4 & 4 & 5 & 4 & 5 & 5 & 5 \\
D & 5 & 5 & 4 & 4 & 5 & 3 & 4 \\
E & 4 & 4 & 4 & 3 & 4 & 4 & 5 \\
F & 4 & 5 & 5 & 5 & 4 & 5 & 3 \\
G & 3 & 4 & 4 & 3 & 4 & 4 & 5 \\
\hline
\end{tabular}

\begin{tabular}{llllllll}
\hline \multirow{2}{*}{$\begin{array}{l}\text { Respon } \\
\text { den }\end{array}$} & \multicolumn{7}{l}{ Nilai Dari Indikator } \\
\cline { 2 - 7 } & $\mathbf{1}$ & $\mathbf{2}$ & $\mathbf{3}$ & $\mathbf{4}$ & $\mathbf{5}$ & $\mathbf{6}$ & $\mathbf{7}$ \\
\hline $\mathrm{H}$ & 4 & 5 & 5 & 4 & 5 & 3 & 4 \\
$\mathrm{I}$ & 4 & 5 & 5 & 3 & 5 & 4 & 4 \\
$\mathrm{~J}$ & 3 & 4 & 3 & 5 & 5 & 3 & 3 \\
$\mathrm{~K}$ & 5 & 4 & 4 & 5 & 3 & 5 & 5 \\
$\mathrm{~L}$ & 4 & 5 & 5 & 5 & 4 & 4 & 4 \\
$\mathrm{M}$ & 3 & 4 & 5 & 3 & 5 & 5 & 3 \\
$\mathrm{~N}$ & 5 & 5 & 4 & 5 & 5 & 4 & 5 \\
O & 5 & 4 & 5 & 5 & 4 & 4 & 4 \\
\hline Total & 63 & 67 & 66 & 61 & 67 & 61 & 64 \\
\hline Persenta & 84 & 89 & 88 & 81 & 89 & 81 & 85 \\
se (\%) & $\%$ & $\%$ & $\%$ & $\%$ & $\%$ & $\%$ & $\%$ \\
\hline
\end{tabular}

Dari hasil UAT pada Tabel 1, dapat dihitung rata-rata penerimaan dari pengguna sangan baik, yaitu $85 \%$

\section{KESIMPULAN}

Berdasarkan hasil penelitian yang telah dilakukan pada PT. Sinar Romindo Indah Tembilahan Provinsi Riau maka dapat diambil kesimpulan yaitu:

(1) penelitian berhasil dalam mengembangkan sistem informasi pemesanan tiket speed boat berbasis web pada PT. Sinar Romindo Indah dan akan digunakan oleh pelanggan, agen dan admin pada perusahaan;

(2) pada pengujian blackbox, dapat diambil kesimpulan bahwa sistem informasi pemesanan tiket speed boat berbasis web dapat diterima dengan baik oleh user (pelanggan) maupun pihak perusahaan;

(3) hasil pengujian user acceptance test menunjukan kinerja sistem $84 \%$, interface $89 \%$, kemudahan menggunakan sistem $88 \%$, Kelancaran sistem $81 \%$, ketepatan informasi $89 \%$, kelengkapan informasi $81 \%$, dan penilaian sistem secara keseluruhan $85 \%$;

(4) dengan adanya sistem informasi pemesanan tiket speed boat berbasis web dapat membantu pelanggan yang yang ingin memesan tiket tanpa harus datang keloket. Sehingga dapat menghemat waktu untuk pelanggan serta mengurangi biaya percetakan tiket dan laporan data penumpang.

\section{REFERENSI}

[1] Swara, dkk. "Rekayasa Perangkat Lunak Pemesanan Tiket Bioskop Berbasis Web”. Jurnal Teknoif. Vol, 4, Nomor 2. 2016.

[2] Inhilkab. "KondisiUmum"[Online]Available,http:// home.inhilkab.go.id/2011/09/page/2/, diakses 23 September, 2011.

[3] Hatta Mohammad., Soelistijadi,R. "Rancang Bangun sistem Informasi Pemesanan Tiket Perjalanan Secara Online Berbasis Web Pada PO.Dewi Sri Pemalang". Jurnal Dinamika Informatika. Vol. 4, Nomor 10. 2012.

[4] Ibrahim Ali. "Perancangan Sistem Pemesanan Tiket Pesawat Berbasis Web". Jurnal Sistem Informasi. Vol. 3, Nomor 1, ISSN: 2085-1588. 2011. 